\title{
Bakti TNI Operation as Implementation of State Defense Strategic Vision Mission
}

\section{Selfira Salsabilla ${ }^{1}$, Aris Sarjito ${ }^{2 *}$}

\author{
1,2 Defense Management, Republik Indonesia Defense University, Bogor, Indonesia
}

\section{ART I CLE I N F O}

\section{Article history:}

Received September 02, 2021

Revised September 04, 2021

Accepted October 20, 2021

Available online November 25, 2021

Keywords:

Defense System, Bakti TNI

Operations, Space, Tools, Fighting Conditions

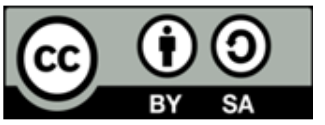

This is an open access article under the CC BY-SA license.

Copyright (C) 2021 by Author. Published by Universitas Pendidikan Ganesha.

\begin{abstract}
A B S T R A C T
Indonesia implements a total defense system where this system involves all components of the nation, which in its implementation is carried out according to their respective capabilities and capacities. one manifestation of the universal defense system is the existence of TNI Operational Service activities. As the implementation of the strategic vision, it is one of the regional development activities to create space, equipment, and harsh combat conditions to ward off threats, challenges, obstacles, and disturbances that may arise in the current strategic environmental conditions. This study aims to analyze the vision and mission of national defense and how the National Defense Strategy Policy in the Framework of Creating Tough Space, Tools and Conditions (RAK Juang) to Support National Defense. This type of research is a literature study approach where the data sources used are journals, articles, books, and other relevant sources. The results of the research are that the achievement of goals in the national defense policy, namely creating a vital fighting space, tools and conditions to support national defense, can be realized through TNI Service Operations activities which are carried out in stages, gradually and integrated with local government development programs so that they can reflect the unity of the TNI. The implementation of military operations to create a formidable battle space with physical activities has contributed to the interests of development in the context of prosperity.
\end{abstract}

\section{INTRODUCTION}

National defense is based on the philosophy and way of life of the Indonesian people to ensure the integrity and the establishment of the Unitary State of the Republic of Indonesia based on Pancasila and the 1945 Constitution (Firdaus \& Zattullah, 2021; Tien et al., 2016). The national goal as stated in the fourth paragraph of the Preamble to the Constitution of the Republic of Indonesia is to protect the entire Indonesian nation and the entire homeland of Indonesia, promote public welfare, educate the nation's life and participate in implementing world order based on independence, eternal peace and social justice (Pramono, 2013; Siagian \& Sumari, 2015). Defense and security are the main things in a country. Defense means keeping it from changing from its original state or keeping and keeping it safe (Andayani, 2020; Marsono et al., 2018; Saragih et al., 2020). National defense is all efforts to defend the state's sovereignty, the territorial integrity of the state, and the nation's safety from threats and disturbances to the integrity of the nation and state (Gummin, 2020; Thomson \& Binder, 2021; Wang, 2018). All national defense is all universal efforts, which are based on awareness of the rights and obligations of the state and belief in one's strength to defend the life of an independent, sovereign, and united Indonesian nation and state (Mantrov, 2015; Staniforth, 2015).

The implementation of state defense is aimed at safeguarding and protecting state sovereignty, territorial integrity and the safety of the entire nation (Martos et al., 2020; Su et al., 2022; Willie et al., 2021). National defense for the Indonesian people is structured in a universal defense system, not aggressive and not expansive in order to protect national interests (Sarkis et al., 2018; Shivanand et al., 2016). The resolution of problems related to and affecting national defense is carried out by prioritizing diplomacy strengthened by modern military forces (Muniz et al., 2021). This implies that the implementation of national defense is not only the duty and responsibility of military institutions, but also includes all existing components of the nation in accordance with the mandate of Law Number 3 of 2002 concerning Defense which regulates the nature of national defense as all defense efforts that are universe whose 
implementation is based on awareness of the rights and obligations of citizens and belief in their own strength. Based on Chapter I paragraph 1 Decree of the Minister of Defense Number: Kep/104/M/I/2020 concerning National Defense Policy in 2020 the implementation of the Indonesian National Defense is a universal people's defense and security system (Sishankamrata) by involving all citizens, regions, and other national resources. Sishankamrata was prepared early by the government and carried out in a total, integrated, directed, and continuous manner to uphold state sovereignty, territorial integrity, and the safety of the entire nation from all threats by taking into account aspects of the development of the strategic environment. In managing the national defense system, the President determines the general policy of national defense, which is further elaborated in the policy on the implementation of national defense which is determined by the Minister of Defense (Asmoro et al., 2021; Octavian et al., 2020). The general policy of implementing national defense which is valid for 5 (five) years becomes a reference for the Ministry of Defense and the TNI to organize national defense. In the context of the implementation of national defense each year, the Minister of Defense determines the national defense policy (Candra et al., 2021; Dipua et al., 2021). For this reason, the author is interested in researching how to implement the strategic vision and mission of the National Defense through Bakti TNI Operation to create space, tools, and tough fighting conditions.

This paper is a development of several previous research results such as the one written by First Lieutenant Cpl Tang Upe in 2011 with the title Optimizing the Implementation of Bakti TNI in the Context of Empowering the Land Defense Area which wrote that Bakti TNI is one method that is considered effective to realize community participation in in order to create the unity of the TNI with the people, as well as in an effort to foster a sense of national unity and integrity. With efforts towards a better direction with various steps that are adapted to the rules and norms that apply, both to the role and function of the Kowil itself through equalizing the vision, mission and perception, as well as the performance of the Kowil apparatus through increasing the five territorial capabilities and activities of the Bakti TNI . Through Operasi Bakti and Karya Bakti which is carried out in essence is to win the hearts of the people by having a good attitude and behavior towards the people so that people's sympathy for the TNI arises so as to encourage the realization of the Unity of the TNI-Society. This condition will give birth to the necessary synergistic strength for efforts to realize the successful implementation of the empowerment of the land defense area which is the task of the Kowil to support the achievement of the national defense policy.

A previous study written by Major General TNI Nanang Djuana Priadi in 2011 entitled A Study on the Implementation of the Bakti TNI Method in the Context of Realizing the territorial construction Target, explained that the implementation of Bakti TNI in order to create a strong fighting space with physical activities has contributed to development interests in for the welfare of society. Building or rehabilitating roads and bridges is closely related to tactical importance because they can be used as approach roads for military operations, while building or rehabilitating places of worship, gates and community houses and the construction of public toilets do not provide a tactical advantage for military operations. The targeting of Bakti TNI is strongly influenced by the targeting process proposed through bottom-up planning. After the two studies above, there is no more research related to how to achieve a tool room and tough fighting conditions through military service operations, for that the author is interested in writing about it. The purpose of this study is to analyze the vision and mission of the National Defense and how the National Defense Strategy Policy in the Framework of Realizing Tough Space, Tools and Conditions (RAK Juang) to Support National Defense.

\section{METHODS}

The method used is a qualitative method using a library research approach, namely research that utilizes library sources to obtain research data, so that in this study the library reference is the main source. The study of literature and data sources in this study was carried out by searching and studying various literatures, scientific articles, both in the form of books, journals and statutory documents related to the implementation of Bakti TNI as an effort to achieve a tool room and strong fighting conditions in the implementation of the vision and national defense strategic mission. Data analysis in this study was conducted through descriptive analysis method, which is defined as an effort to collect and compile data, then analyze the data. This research uses Law Number 3 Of 2002 Concerning State Defense and A Guidebook For The Organization Of Bakti TNI Operations is provided by the army headquarters which is faced with the dynamics of implementation in the field. The Decree of the Minister of Defense Number: Kep / 104 / M / I / 2020 concerning National Defense Policy in 2020 is also the main basis in this paper because this paper discusses how to achieve the strategic objectives contained in the decision through military service operations. 


\section{RESULTS AND DISCUSSIONS}

\section{Results}

The United Nations (1975) gives the meaning of policy in the form of a declaration regarding a basic guideline for action, a certain course of action, a program regarding certain activities or a certain plan, a program regarding certain activities. certain or a certain plan. Policies are essentially guidelines for action. These guidelines may be very simple or complex, general or specific, broad or narrow, vague or clear, loose or detailed, qualitative or quantitative, public or private. The policy is "A purposive course of action followed by an actor or set of actors in dealing with a problem or matters of concern". or a group of actors to solve a particular problem. Whereas in the implementation of defense, basic guidelines are also made that contain certain objectives. Guidelines can be general or specific, in the State defense policy. The guidelines are generally contained in Presidential Regulation Number 8 of 2021 concerning General National Defense Policy while the guidelines are specifically regulated in the Decree of the Minister of Defense Number: Kep/104/M/I/2020 concerning State Defense Policy in 2020.

General guidelines for the management of national defense are prepared based on the vision and mission of the government in the field of defense and policies for the implementation of national defense in 2020-2024 in order to realize a single defense unit in the context of achieving national goals. To achieve this, the management of the national defense system is oriented to the integration of military defense and non-military defense as a form of universality in the national defense system by referring to strategic goals and objectives as well as national defense policies. As stated in the Decree of the Minister of Defense Number: Kep/104/M/I/2020 concerning State Defense Policy in 2020 that the Vision and Mission of the Defense Sector for 2020-2024 are based on the vision and mission of the government in 2020-2024, as follows. Vision: The realization of an advanced Indonesia that is sovereign, independent, and has personality, based on mutual cooperation. Mission: Protection for All Nations and Providing Security for All Citizens, carried out through a continuation program of Modern Defense System Transformation and Professionalof TNI. This vision and mission is then realized in the general policy of national defense which aims to maintain the sovereignty and territorial integrity of the Unitary Republic of Indonesia and protect the safety of the entire nation from all forms of threats, the establishment of an integrated and modern People's Defense and Security System (Sishankamrata), the realization of National Resource Management. PSDN), for National Defense, and the implementation of defense area management.

That based on President Regulation Number 8 of 2020 concerning the general policy of state defense, it contains provisions regarding military policies relating to the development of military defense capabilities directed at the capabilities of the Main Components, which are supported by the Reserve Components and Supporting Components, including the policy of fostering the main components of the land force directed to protect, maintain and enforce sovereignty on land, realize the operational readiness of the Indonesian Armed Forces, and master technology. This was later clarified by the State Defense Policy as stated in the Decree of the Minister of Defense Number: Kep / 104 / M / I / 2020 concerning State Defense Policy in 2020 that to realize the planned objectives, strategic targets are needed in the State defense policy. One of these targets is the implementation of the management of the defense area through the realization of tough space, tools and fighting conditions (RAK Juang) to support the National Defense.

The realization of space, tools and tough fighting conditions can be done through the implementation of the Bakti TNI method as one of the Territorial Development methods to deal with various forms of threats and realize the unity of the TNI-Society as TNI's strength in carrying out their duties. TNI Service Operations are the participation of the TNI as a means of state defense in the context of regional development in the physical and mental spiritual fields which are carried out on the orders of the TNI Commander by utilizing all available resources in the context of TNI Service. TNI Service Operations can be carried out in the form of TMMD (TNI Manunggal Membangun Desa) where this activity is an annual Army program that has complex target dimensions and is oriented towards community empowerment in its implementation. This TMMD is carried out by a regional command unit at the Kodim level by involving all components of the community and other resources. In addition, there is also the TNI Manunggal KB and Health program where this activity focuses on implementing family planning services and improving health services, especially toddlers and children and other vulnerable groups (Book II Guidelines for the Implementation of TMMD For Year 2021 p. 6). In 2020 the Indonesian Army has a new program called Community Empowerment Social Service where this activity is an integrated activity that provides appropriate training to improve welfare.

Fighting space is the embodiment of a defense area that is ready as a mandala perang or an mandala operasi that supports the interests of the unit's own operations in winning the battle. The fighting space is a manifestation of the results of the development of geographic potential which includes the fields of natural resources and artificial resources with all the potential of natural resources being fostered into geographic strength in the form of a strong fighting space and having regional deterrence for defense purposes. TNI 
Service Activities that have been programmed and implemented related to the interests of a strong fighting space include: first, one of the main targets of the TNI Manunggal Membangun Desa Task Force is to open new roads, improve road quality, build or repair bridges and other infrastructure in order to transform existing development to accommodate defense interests, especially applications as an approach in times of war and become a means of improvement standard of living and welfare of the people in peacetime. Second, the TMMD Task Force also has supporting targets that are tailored to regional needs, such as building clean and drinking water supply facilities, proper sanitation facilities, rice field irrigation channels and other agricultural support facilities for the benefit of regional logistics resources. Third, the TNI Manunggal Reforestation Service Operation (TMR) realizes forest preservation as a buffer for regional ecosystems to prevent the dangers of natural disasters, floods and landslides often caused by a large number of denuded forests, for that the TNI actively participates in collaborating with local governments to assist the implementation of the reforestation program. This activity also aims to launch the forest as a protected area for review and shooting protection during the war. Meanwhile, for coastal areas whose communities are fishermen, the TMMD Program is directed to rehabilitate docks, provide small-scale power plants for the benefit of strategic material reserves during emergency conditions if they are maintained and their construction improved.

Regional Military Commands, Military Resort Commands and Military District Commands are designed as strategic parts that have ability to realize defense and resistance independently and continuously and are capable of carrying out defense in the form of single-force operations or overall joint operations on large islands and a series of small islands. in the area of operation. The implementation of regional defense is stated in the Land Defense Regional Spatial Plan (RTRW) which is prepared based on possible threats, so that in the concept of implementing the Bakti TNI method in the context of realizing the target of developing territorial defense, it is necessary to prepare a defense area which includes the battle area, communication area, rear area and area. which can be used as a fulcrum and facilitate regional resistance operations known as the base of resistance areas to support land defense strategies. The implementation of the Bakti TNI method to prepare the base area for resistance in order to create a strong fighting space, its activities lead to physical activities and regional infrastructure. When viewed from the achievement of development goals, the opening of roads and bridges has added value to the expansion of spatial planning and opened new land routes that connect between villages. In addition, the opening of roads can speed up the process of regional expansion in accordance with the development objectives set by the regional government in accordance with the regional spatial plan and general spatial planning prepared by the Regional Development Planning Agency (Bappeda).

In a sense, fighting tools is the availability of backup and support components that have been organized in a real way with all the tools ready to be used as a multiplier force to win the battle. Fighting tools can also be interpreted as an embodiment of the results of the development of demographic potential that is fostered into demographic strength in the form of a formidable fighting tool and has regional deterrence to ward off the threat of emerging obstacles and disturbances. The development of this potential aims to realize the participation of the people as a reserve component and a supporting component whose service is adjusted to the profession. Bakti TNI activities which have been programmed and implemented through physical and non-physical activities carried out in collaboration with the Regional Government through service and counseling activities such as: First, Improving public and environmental health services, through this activity the community will feel the real presence of the State to improve welfare so that they will voluntarily participate in efforts to defend the State in accordance with their competence and capacity. Second, Bringing appropriate technology closer to the community in the target area to create job opportunities and improve the wheels of the economy of an independent community in the area. The implementation is through the Community Empowerment Social Service program where the activity is an effective training for the community involving local government agencies or agencies according to the field; Third, Raise public awareness to have a culture of mutual cooperation and actively participate in developing their own region as a form of participating in efforts to defend the state. Fourth, Increase national insight in the life of society, nation and state as well as awareness of defending the country; And Growing public awareness in a culture of discipline and order in the law in order to improve security stability.

Efforts made in determining the Bakti TNI program, in particular to realize a formidable fighting tool, are coordinated with the Regional Government through these outreach activities so that the community has a high sense of nationality and provides preparedness training with the content of environmental security system (Siskamling) and disaster response training as well as quick report training. and quick meetings in an effort to prepare communities that are responsive to regional situations. The development of fighting equipment is not only carried out programmatically through special activities, but is also carried out in stages and continues by the Babinsa (Bintara Pembina Desa) which is attached to the community every day. In accordance with the four main tasks of Babinsa based on Army Chief of Staff 
Regulation Number 54 of 2014 concerning the ratification of the Organization and Duties of the Type A Military District Command (Orgas Koramil Type A) namely: first, Carry out Territorial Guidance according to the instructions of the Koramil Commander. Second, Carry out data collection on geography, demography, social conditions and national potential including Human Resources, Natural Resources/Artificial Resources, as well as facilities and infrastructure in the region. Third, Provide information about the situation and condition of the area for troops serving in the area; and Reporting the development of the situation to the Danramil at the first opportunity. The description of the task above has one goal, namely the achievement of the target of territorial development to realize a formidable fighting tool in the form of the availability of reserve components and supporting components that have been clearly organized with all the equipment ready to be used for multiplier forces in winning the battle in the event of a war.

\section{Discussion}

The implementation of Bakti TNI is carried out as an effort to establish strong fighting conditions, fighting conditions are dynamic conditions of society in the life of society, nation and state which are reflected in attitudes and behaviors that are imbued with love for the Unitary State of the Republic of Indonesia based on Pancasila and the 1945 Constitution, responsible and willing to sacrifice in the service of the nation and the State. The fighting condition is a manifestation of the results of fostering the potential for social conditions to become a defense force, so that the region has a strong territorial deterrent, judged from several aspects and is able to support the interests of national defense (Andayani, 2020; Marsono et al., 2018). The aspect of the fighting condition is an aspect of the social condition of the community which includes ideology, politics, economy, socio-culture and defense and security (Gummin, 2020; Hardiyanto, 2021). Ideology. The TNI's service which is directed towards social development of the community in the field of ideology is carried out through non-physical activities, including: first, provide integrated and sustainable counseling to instill public confidence in Pancasila as the philosophy and ideology of the state. Second, conducting outreach about the latent dangers of Communists, and Preventing Countering Radicalism through Social Communication activities together with Government Officials and Religious Leaders, Community Leaders and Local Traditional Leaders.

The service of the TNI which is directed at fostering the community in the political field is carried out through non-physical activities, including: first, carry out outreach activities and lectures to increase awareness and understanding of the rights and obligations as citizens in accordance with applicable laws and regulations (Ambarsari \& Risman, 2019; Kustana, 2017; Tarigan \& Saputro, 2021). Second, encouraging the public to always comply with legal provisions and other norms in daily life. Third, encouraging the public to always prioritize the public interest, the nation and the state above personal and group interests. The service of the TNI which is directed at developing the community in the economic field is carried out through physical and non-physical activities, including: first, providing knowledge to the public about the negative impact of a consumptive lifestyle (Supandi et al., 2016; Wahyudi et al., 2016). Second, promoting the spirit of buying Indonesian products as an effort to increase awareness of defending the country. Third, assist the government in increasing the intensification of fisheries, agriculture, plantations, animal husbandry, and MSMEs that are implemented in an integrated manner and empowerment in other sectors. Whereas currently the Indonesian Army has a Social Service Program for Increasing Community Selfreliance in collaboration with local government agencies according to their respective fields in the context of improving the community-based economy and local wisdom.

Socio-Cultural Field. The service of the TNI is directed at fostering the community in the sociocultural field, with activities including: first, provide counseling about the importance of tolerance in religious life to the community. Second, provide education about the importance of environmental hygiene and health to the community (Basworo, 2017; Kaprisma, 2020; Tobing \& Muradi, 2015). Third, promote sports activities and carry out sports activities with the TNI and the community. Fourth, Preserving and developing various forms of art, culture and customs in the community as a means of socializing the values of national and state life, because cultural facilities are the most effective and efficient means of promoting these values. Security Defense. The service of the TNI is directed at fostering the community in the field of defense and security, with activities including: first, cultivate the obligation to report to the security forces, if there are developments in the situation that occur in the community (Andayani, 2020; Marsono et al., 2018; Staniforth, 2015). Because at this time the community tends to be passive and ignore the surrounding environment because they feel that there are officers. Second, encouraging the public to take part in state defense education that has been programmed by the government through the educational environment, and workers. As currently, the activities of the School Environment Introduction Period (MPLS) are often filled with preliminary education activities to defend the State, this is also carried out by several companies, both private and public, which are applied to new employees. Third, reinvigorating the activities of the Environmental Security Post (Poskamling) in the community on an independent basis, currently many 
villages use the services of a security unit, so there is no sense of responsibility as citizens for the security of their own area.

\section{CONCLUSION}

The achievement of the objectives in the national defense policy, namely to realize strong fighting space, tools and conditions in supporting the national defense, can be realized through the Bakti TNI Operations activities which are carried out in stages, stages and continuously and are integrated with the regional government development program so that it can reflect the unity of the People's Armed Forces. The implementation of military service operations in the context of creating a formidable fighting space with physical activities has contributed to the interests of development in the context of the welfare of the community. Building or rehabilitating roads, bridges is closely related to the realization of the binter target in supporting tactical interests because it can be used as an approach road for military operations, and the availability of people who have a responsibility to participate in maintaining the survival of the nation and state in accordance with the concept of developing the demographic aspect. To be directed to become a formidable fighting tool with the availability of reserve components and supporting components that have been clearly organized with all of its tools that have a love for their homeland, namely the unitary state of the Republic Of Indonesia, which is based on Pancasila and the 1945 Constitution, is responsible and willing to sacrifice in the service of the nation and country.

\section{REFERENCES}

Ambarsari, K. W., \& Risman, H. (2019). The Indonesian National Armed Forces (Tni) And Falintil- Forças De Defesa De Timor Leste (F-Fdtl)'S Defense Diplomacy: A Way Of Conflict Resolution In Timor Leste. Jurnal Pertahanan, 5(3). https://doi.org/10.33172/jp.v5i3.617.

Andayani, L. (2020). Indonesian Diaspora Empowerment: A Concept In Strengthening Diplomacy For National Defense. Jurnal Pertahanan, 6(1). https://doi.org/10.33172/jp.v6i1.731.

Asmoro, N., Sutomo, A., Haryono, T., \& Putri, R. (2021). The Structuring Of Organizational And Doctrine Of State Defense In Facing Hybrid Warfare. Jurnal Pertahanan, 7(2). https://doi.org/10.33172/jp.v7i2.1220.

Basworo, gregorius henu. (2017). Kinship System Border as Social Capital Community. Jurnal Pertahanan, 3(1). https://doi.org/10.33172/jp.v3i1.161.

Candra, A., Suhardi, S., \& Persadha, P. D. (2021). Indonesia Facing The Threat Of Cyber Warfare: A Strategy Analysis. Jurnal Pertahanan, 7(3). https://doi.org/10.33172/jp.v7i3.1424.

Dipua, A., Prakoso, L. Y., \& Nurdiansyah, D. R. (2021). Analysis Of Defense Strategy Policies In Dealing With The Potential Negative Impacts Of The South China Sea Conflict. Jurnal Pertahanan, 7(1). https://doi.org/10.33172/jp.v7i1.860.

Firdaus, A., \& Zattullah, N. (2021). Upaya Meningkatkan Kecerdasan Budaya, Kompetensi Lintas Budaya dan Ketahanan bagi Peacekeeper dalam Misi Perdamaian PBB. Pendipa: Jurnal Pendidikan Sains Universitas Bengkulu, 6(1). https://doi.org/10.33369/pendipa.6.1.169-176.

Gummin, D. D. (2020). Potent opioids and implications for national defense. Toxicology Letters, 321. https://doi.org/10.1016/j.toxlet.2019.12.017.

Hardiyanto, B. (2021). Politics of land policies in Indonesia in the era of President Susilo Bambang Yudhoyono. Land Use Policy, 101. https://doi.org/10.1016/j.landusepol.2020.105134.

Kaprisma, H. (2020). Psychological Operations: From The Communication, Media, Propaganda, And SocioCultural Perspective. Jurnal Pertahanan, 6(2). https://doi.org/10.33172/jp.v6i2.492.

Kustana, T. (2017). Islamic terrorism in Indonesia: Addressing Government Strategies and Muslim Population. Jurnal Pertahanan, 3(2). https://doi.org/10.33172/jp.v3i2.145.

Mantrov, V. (2015). Available Defences in Provisional measures: Between the Enforcement Directive and National law. International Comparative Jurisprudence, 1(1). https://doi.org/10.1016/j.icj.2015.10.001.

Marsono, M., Deni, \& Asmoro, N. (2018). Improvement Of Japanese Military Capabilities And Implications On Indonesia's National Defense. Jurnal Pertahanan, 4(2). https://doi.org/10.33172/jp.v4i2.286.

Martos, G. G., Grau, R. H. T., Marino, C., Mamani, A., \& Ricci, J. C. D. (2020). Defense elicitation activity of the ellagitannin HeT depends on its redox state. Scientia Horticulturae, 267. https://doi.org/10.1016/j.scienta.2020.109312.

Muniz, A. M. de S., Sizenando, D., Lobo, G., Neves, E. B., Gonçalves, M., \& Marson, R. (2021). Effects from loaded walking with polyurethane and styrene-butadiene rubber midsole military boots on kinematics and external forces: A statistical parametric mapping analysis. Applied Ergonomics, 94. https://doi.org/10.1016/j.apergo.2021.103429. 
Octavian, A., Asmara, R., \& Hidayat, A. S. (2020). Means Of Indonesian Maritime Defense Strategy In Sea Control On The Indonesian Strategic Straits To Support Total Defense And Security System. Jurnal Pertahanan, 6(3). https://doi.org/10.33172/jp.v6i3.1130.

Pramono, A. (2013). Orbit Geostasioner (GSO) dalam Hukum Internasional dan Kepentingan Nasional Indonesia. Pandecta: Research Law Journal, 6(2). https://doi.org/10.15294/pandecta.v6i2.2331.

Saragih, H. J., Suhirwan, S., Sarjito, A., Damanik, Y. D., \& Avalokitesvari, N. N. A. N. (2020). Management Of Defense Heritage Based Tourism To Enhance Youth Nationalism And Patriotism. Jurnal Pertahanan, 6(2). https://doi.org/10.33172/jp.v6i2.847.

Sarkis, S., Dabo, S., Lise, M.-C., Neuveut, C., Meurs, E. F., Lacoste, V., \& Lavergne, A. (2018). A potential robust antiviral defense state in the common vampire bat: Expression, induction and molecular characterization of the three interferon-stimulated genes -OAS1, ADAR1 and PKR. Developmental \& Comparative Immunology, 85. https: //doi.org/10.1016/j.dci.2018.04.006.

Shivanand, G., Reddy, K. V. K., \& Prasad, D. (2016). An Innovative Asynchronous, Multi-rate, Multi-sensor State Vector Fusion Algorithm for Air Defence Applications. IFAC-PapersOnLine, 49(1). https://doi.org/10.1016/j.ifacol.2016.03.076.

Siagian, B. D. O., \& Sumari, A. D. W. (2015). Radicalism Discourse Analysis on Online Sites in Indonesia: The Perspective of National Security. Jurnal Pertahanan, 1(2). https://doi.org/10.33172/jp.v1i2.57.

Staniforth, A. (2015). Port and Border Security: The First and Last Line of National Security Defense. Strategic Intelligence Management. https://doi.org/10.1016/B978-0-12-407191-9.00005-3.

Su, Q., Wang, H., Sun, C., Li, B., \& Li, J. (2022). Cyber-attacks against cyber-physical power systems security: State estimation, attacks reconstruction and defense strategy. Applied Mathematics and Computation, 143. https://doi.org/10.1016/j.amc.2021.126639.

Supandi, S., Sahabuddin, Z. A., \& Amperiawan, G. (2016). Community Economic Empowerment in Achieving National Defense. Jurnal Pertahanan, 2(2). https://doi.org/10.33172/jp.v2i2.94.

Tarigan, H., \& Saputro, G. E. (2021). The Role Of The Indonesian National Army (Tni) In Countering Terrorism. Jurnal Pertahanan, 7(1). https://doi.org/10.33172/jp.v7i1.1167.

Thomson, M. D. J. M., \& Binder, C. M. (2021). Recalibrating the Department of National Defence approach to active sonar impact management. Marine Pollution Bulletin, 173. https://doi.org/10.1016/j.marpolbul.2021.113044.

Tien, M. A., Wahyudi, E., \& Soekarno, G. (2016). Prespektif Peran Mahasiswa Dalam Bela Negara. Perspektif Hukum Journal, 13(1). https://doi.org/10.30649/phj.v13i1.46.

Tobing, V., \& Muradi, M. (2015). National Security Systems on The Threat Perception Index. Jurnal Pertahanan, 1(2). https://doi.org/10.33172/jp.v1i2.60.

Wahyudi, B., Midhio, I. W., \& Waluyo, S. D. (2016). Creative Economy Development of Yogyakarta Government. Jurnal Pertahanan, 2(1). https://doi.org/10.33172/jp.v2i1.78.

Wang, H.-L. (2018). Perception of safety culture: Surveying the aviation divisions of Ministry of National Defense, Taiwan, Republic of China. Safety Science, 108. https://doi.org/10.1016/j.ssci.2018.04.022.

Willie, T. C., Linton, S. L., Whittaker, S., Martinez, I., \& Sharpless, L. (2021). "There's no place like home": Examining the associations between state eviction defense protections and indicators of biopsychosocial stress among survivors of intimate partner violence. Social Science \& Medicine, 279. https://doi.org/10.1016/j.socscimed.2021.113957. 